\title{
O perspectivă asupra lexicului comun latinei clasice şi latinei vulgare
}

\author{
George Bogdan Țâra* \\ Facultatea de Litere, Istorie și Teologie, Universitatea de Vest, Bd. Vasile Pârvan 4, 300223 Timişoara, România
}

\section{Despre articol}

Istoric:

Primit 17 februarie 2017

Acceptat 15 ianuarie 2018

Publicat 27 aprilie 2018

Cuvinte-cheie:

diacronie

istoria limbii

lexicologie istorică

semantică istorică

variantă literară

\begin{abstract}
Rezumat
Articolul are ca punct de plecare perspectiva diferită a latiniștilor și a romaniștilor asupra conceptului de 'latină vulgară, concretizată în polemica amicală dintre Pierre Flobert și Eugeniu Coșeriu. Avînd în vedere lexicul limbii latine, încercăm să arătăm o seamă de elemente comune între latina clasică și latina vulgară. În demersul nostru, am considerat, asemenea Mariei Iliescu, că viziunea diacronică asupra limbii trebuie să aibă în vedere suma istoriilor cuvintelor ce o compun. Spațiul restrîns al unui articol ne-a determinat să alegem un număr limitat de lexeme atestate în scris. Pe baza exemplelor excerptate din texte aparținînd unor epoci diferite ale literaturii latine (arhaică, clasică, tîrzie), de la autori clasici (Cicero, Vergilius etc.) și de la scriitori ale căror opere conțin elemente de limbă vorbită (Plautus, Petronius etc.), din lucrări cu un nivel ridicat de limbă (epopee, discurs, tratat etc.) și din texte cu mărci ale oralităţii (comedii, corespondență, predici), am putut observa evoluția semantică a unor termeni păstrați în limbile romanice. Concluzia noastră susține ideea de 'limbă comună, care explică existența în paralel a aceloraşi termeni (casa, pauimentum, caballus, formosus, uetulus, auricula, gula, bucca, manducare, incendere, draco) în latina clasică și în latina vulgară, fără diferențe notabile.
\end{abstract}

\section{Introducere}

Conceptul de 'latină vulgară’ sau 'latină populară, aflat la baza lingvisticii romanice, a suscitat discuții contradictorii chiar înainte de consacrarea lingvisticii ca știință, în secolul al XIX-lea. Nu dorim să intrăm în aceste dispute în care s-au pronunțat pînă acum lingviști celebri, concepțiile lor fiind preluate și continuate de școli lingvistice bine conturate.

Totuși, la baza articolului nostru se află două perspective diferite asupra acestui concept, una făcută de pe poziția de latinist, a profesorului Pierre Flobert, cealaltă, din perspectiva de romanist, a lingviștilor Eugeniu Coșeriu și Maria Iliescu.

Observațiile noastre asupra conceptului de 'latină vulgară' vor avea în vedere doar aspectul lexical. Această limitare, impusă de dimensiunile unui articol, ne va permite să urmărim, în cazul concret al unor lexeme, pe baza atestării lor continue de-a lungul latinităţii, la autori diferiți, apartenenţa lor la un inventar de cuvinte comune atît conceptului de 'latină vulgară', cît și celui de 'latină clasică. Considerăm că acest demers merită aprofundat în perioada actuală, cînd cercetătorul are la dispoziție instrumente informatice care îl ajută la identificarea ocurențelor și la înțelegerea contextelor apariției oricărui lexem în limba latină. La baza acestui tip de cercetare se află perspectiva afirmată de M. Iliescu în acord cu E. Coșeriu: „Enfin, on ne considère plus l'histoire d'une langue comme l'histoire d'un tout, d'un complexe unitaire, mais comme la somme des histoires de formes et de mots"1 (Iliescu, 2013, p. 139).

\footnotetext{
*Adresă de corespondență: tarabogdan@yahoo.fr.

${ }^{1}$ „În sfîrșit, nu mai considerăm istoria unei limbi ca istoria unui tot, a unui complex unitar, ci ca suma istoriilor formelor și cuvintelor".
} 


\section{Latina ,vulgară”}

Încercările de definire a noțiunii de 'latină vulgară’ nu sînt unitare, lucru reflectat și de varietatea denumirilor propuse pentru unul și acelaşi concept.

În primul rînd, trebuie subliniat faptul că acesta se subsumează, asemenea conceptului de 'latină creștină, ideii de 'limbă latină’ în integralitatea sa, fără a desemna o limbă diferită, tendință afirmată la începutul lingvisticii: „Au XIX ${ }^{\mathrm{e}}$ s. une grande partie des linguistes croyait que le latin vulgaire était une 'autre' langue latine, parlée par le 'peuple' qui se différenciait nettement du latin des personnes cultivées, du latin des auteurs" ${ }^{2}$ (Iliescu, 2013, p. 138). Nici din perspectiva romanisticii, nu se mai acceptă în lingvistica actuală imaginea unei limbi unice, ca idiom de tranziţie între latină și limbile derivate din aceasta: „Ideea unei latine «vulgare» rigid unitare, care ar constitui «baza» comună și exclusivă a tuturor limbilor romanice este un reziduu al nefericitei concepții a «limbilor primitive» (Ursprachen)” (Coșeriu, 1997, p. 154, nota 59).

Dacă Grandgent (1907) considera că latina vulgară era „,vorbirea claselor de mijloc”, Herman (1967) o înțelegea ca fiind „limba vorbită de păturile puțin sau deloc influențate de învățătura școlară și de modelele literare”, iar B.E. Vidos (1959, p. 201, apud Haadsma \& Nuchelmans, 1963, p. 16), extindea conceptul la „limba vorbită de toate păturile populației, în toate perioadele latinității”. Reținem ca element comun al definiţiilor de mai sus ideea de limbă vorbită, deci dinamică, supusă în primul rînd uzului și mult mai puțin regulilor sistemului gramatical, aflată, astfel, în opoziție cu varianta scrisă, cultivată.

Demarcaţia dintre latina scrisă și cea vorbită nu este, însă, una absolută, deoarece relațiile între cele două variante ale aceleiaşi limbi sînt permanente de-a lungul întregii latinităţi. Fiind ulterioară latinei vorbite și existînd în paralel cu aceasta, latina scrisă, care dobîndește un aspect literar în timp, s-a constituit pe baza unui lexic existent și a unor structuri gramaticale și comunicaţionale care au devenit comune exprimării orale și scrise. Rafinarea acestora în scris, în paralel cu evoluția lor în vorbire, nu a condus la o ruptură decisivă, dimpotrivă: „le latin écrit a toujours suivi-parfois d'assez loin, évidemment-les transformations de la langue usuelle. Inversement, le style écrit, prestigieux, a marqué la langue parlée, dont le développement n’a pas été isolé et linéaire”3 (Flobert, 2014, p. 434).

Văzută astfel, din perspectivă latinistă, limba „vulgară” se apropie de „limbajul liber al conversației”, „latina tuturor”, ,latina neîngrijită” („sans art”), „limba uzuală” sau, cel mai bine, sermo cottidianus, care nu denumește o latină specială, ci „uzul normal” (v. Flobert, 2014, p. 428).

Toate aceste noțiuni existau deja în perioada antichităţii latine la diverşi scriitori, a căror perspectivă este „peste tot una stilistică”, atrage atenția Flobert (2014, p. 429). Același autor, aducînd argumente de la Plautus, Cicero, Varro și Quintilianus, arată că, de fapt, rusticus este „adjectivul cel mai marcat social și gramatical” (Flobert, 2014, p. 429) pentru a numi un nivel inferior al latinei, caracterizat prin „pronunții de tip rural” și de „termeni ca la țară” ${ }^{4}$. Abia în latina tîrzie, începînd din secolul IV p.C., la autorii creștini apare clar interesul de a se apropia de această latină a oamenilor fără școală, semn că diferențele deveniseră pregnante. Pierre Flobert subliniază, așadar, opoziția între cottidianus, care ține de stil, dar fiind corect, și rusticus, asemenea perifrazelor cu vulgo, care va caracteriza în cele din urmă, abia din secolul VI, limba cu greșeli, separată de latina din școală (v. Flobert, 2014, p. 429-430). Reiese că, cel puțin pînă în secolul VI, dată de la care, din perspectivă romanică, isoglosele comune latinei clasice și latinei vulgare se reduc în favoarea creării de noi subsisteme ${ }^{5}$, aşa-zisa 'latină vulgară’ și așa-numita 'latină clasică vor număra mai

${ }^{2}$ „În secolul al XIX-lea, o mare parte a lingviștilor credeau că latina vulgară era o «altă » limbă latină, vorbită de «popor», care se deosebea în mod clar de latina persoanelor cultivate, de latina autorilor".

3 „[...] latina scrisă a urmat întotdeauna-uneori destul de departe, evident-transformările din limba uzuală. În sens invers, stilul scris, prestigios, a marcat limba vorbită, a cărei dezvoltare n-a fost izolată și lineară”.

${ }^{4}$ „Les urbani dénoncent à l'envi les prononciations rurales souvent admises dans l'usage (olus, foresis, coda) et les termes qui sentent la compagne (caballus, scrofa)" [Urbani acuză care mai de care pronunțiile rurale admise adesea în uz (olus, foresis, coda) și termenii cu iz de țară (caballus, scrofa)] (Flobert, 2014, p. 429).

${ }^{5}$ „Les isoglosses communes des deux aspects du latin, au commencement nombreuses, se sont réduites de plus en plus, 
multe elemente comune decît diferențiatoare. Or, perioada menționată, extrem de vastă (în jur de șapte secole), cuprinde nu numai cucerirea noilor provincii romane, ci și procesul de romanizare a lor. În aceste condiții, noțiunea de 'latină vulgară, ca limbă vorbită ${ }^{6}$ de-a lungul întregii latinităţi, se identifică cu însăși limba latină, limbă cu variații firești, dar inegale, diatopice, diacronice și diafazice, dintre care unele se reflectă în limba scrisă, altele, cum este cea mai mare parte a lexicului, sînt chiar comune cu limba literară.

Din perspectivă inversă, romanistă $\breve{7}^{7}$ latina vulgară este liantul necesar, dar nu suficient, între limba latină atestată şi formele ei păstrate în limbile romanice. Se știe că pînă în secolul VI s-a vorbit latina, iar din secolul VIII, romanica. Sînt cel puțin două secole de transformări ale căror cauze nu se explică doar prin evoluție lingvistică, ci și istorică, socială, culturală etc. Cert este că ele nu mai au legătură cu epoca în care s-a făcut romanizarea și, probabil, nici cu purtătorii limbii latine în provincii, ci cu evoluții la limita dintre latina tîrzie, cînd latina era încă o limbă vorbită, și latina medievală, cînd latina devenise preponderent o limbă a comunicării scrise, poate chiar evoluții de dată romanică (reforma carolingiană).

Imaginea propusă de însuși Diez, a unei latine populare (Volkslatein) care evoluează prelungindu-se în limbile romanice, este combătută cu vehemență de pe poziția latinistului care merge pînă la a o considera un concept fără acoperire în realitate: „C'est ainsi que le latin parlé, variante stylistique du latin, hypostasié en une langue qui « n’a jamais existé que dans les cerveaux de quelques savants », s'est imposé chez les romanistes sous le nom impropre de latin « vulgaire ». C'est évidemment plus confortable que de lire les travaux des latinistes..." (Flobert, 2014, p. 436). Un răspuns împotriva unui verdict atît de tranșant a fost dat de E. Coșeriu în articolul Le latin vulgaire des romanistes, scris în ultimele săptămîni de viață și publicat postum de Benjamín García-Hernández. Deși nu susține concepția prietenului său francez, justificînd existența conceptului de 'latină vulgară, punctele de dezacord nu sînt numeroase. În ce privește semnificația termenului vulgar, E. Coșeriu precizează că acesta se apropie de accepțiunea pe care P. Flobert o dădea lui cottidianus: „Le Volgare (sans adjectif, certes, c'est déjà l'italien, mais appliqué à une autre langue, le terme signifie 'la langue courante', 'la langue couramment parlée', c'est-à-dire, il a à peu près la valeur que Flobert attribue à cottidianus"' (Coșeriu, 2005, p. 21). Concluzia marelui savant trădează, într-adevăr, o perspectivă diferită a cercetătorilor romaniști față de tradiția latinistă, deoarece diversitatea limbilor cu origine latină, unitare și în acelaşi timp diferite, presupune existența unui stadiu al limbii latine care să conțină în el ambele tendințe: „Or, pour justifier cette unité et pour justifier en même temps les différences qu'on constate entre les langues romanes, [il faut admettre une forme de latin qui contenait déjà ce phénomène, c'est-à-dire, le phénomène qui allait devenir panroman]" ${ }^{10}$ (Coșeriu, 2005, p. 23) ${ }^{11}$.

même si jusqu'au commencement du VI ${ }^{\mathrm{e}}$ s. les isoglosses communes, bien que moins nombreuses, étaient encore plus importantes que celles qui commençaient déjà à se constituer en sous-systèmes différenciés." [Isoglosele comune celor două aspecte ale latinei, la început numeroase, s-au redus din ce în ce mai mult, chiar dacă, pînă la începutul secolului al VI-lea, isoglosele comune, deși mai puține la număr, erau încă mai importante decît cele care începeau deja să se constituie în subsisteme diferențiate.] (Iliescu, 2013, p. 140).

${ }^{6}$ Se consideră că nu există texte în latină vulgară, ci doar texte care conțin vulgarisme.

${ }^{7}$ „Au contraire, la plupart des romanistes, encore aujourd'hui, raisonnent inductivement à partir des faits romans en faisant grand usage du latin « vulgaire » protéiforme et complaisant; leur carapace théorique est trop souvent spécieuse." [Dimpotrivă, cea mai mare parte a romaniștilor, încă și astăzi, judecă inductiv pornind de la faptele din romanică, folosindu-se din plin de latina «vulgară » [concept] proteiform şi complezent; carapacea lor teoretică este prea adesea înșelătoare.] (Flobert, 2014, p. 435).

${ }^{8}$ „Astfel se face că latina vorbită, variantă stilistică a latinei, ipostaziată într-o limbă care «n-a existat niciodată decît în creierele cîtorva savanți», s-a impus la romaniști sub numele impropriu de latină «vulgară». Este, desigur, mai confortabil decît să citești lucrările latiniștilor...”.

${ }^{9}$ „Volgare (fără adjectiv), desigur, este deja italiana, însă aplicat unei alte limbi, termenul semnifică 'limba curentă, 'limba vorbită în mod curent', adică are aproape aceeași valoare cu cea pe care Flobert o atribuie lui cottidianus”.

${ }^{10}$ „Or, pentru a justifica această unitate și pentru a justifica în același timp diferențele care se constată între limbile romanice, [trebuie să admitem o formă de latină care conținea deja acest fenomen, anume fenomenul care urma să devină panroman]”.

${ }^{11}$ Benjamín García-Hernández, care a adăugat această completare făcută de E. Coșeriu pe patul de spital cu numai cincisprezece zile înainte de deces, adaugă următoarea precizare referitoare la viziunea de ansamblu a savantului: „Pour lui, latin vulgaire et latin classique constituent deux niveaux d'un même continuum, de façon que latin vulgaire est tout le latin qui se développe et s'éloigne du latin fixé, c'est-à-dire, du latin littéraire qui, lui, ne se déroule pas en accord avec la langue parlée” 
De fapt, E. Coșeriu susține, și cu această ocazie, concepția asupra latinei vulgare detaliată deja în 1954, în lucrarea El llamado "latín vulgar" y las primeras differenciaciones romances, care a devenit de referință in cercetările de lingvistică romanică. $\mathrm{Cu}$ acea ocazie arătase că latina vulgară nu poate fi identificată cu o limbă istorică reală, ci este o abstracțiune care ajută la explicarea elementului latin moștenit în limbile romanice. Fiind un concept amplu, include elemente din latina clasică, forme anterioare care nu au intrat în aceasta, precum și forme mai recente. Mai variată decît latina clasică, ea cuprinde și elemente care dovedesc diferențe regionale, sociale, stilistice și cronologice.

Asupra denumirii noțiunii, trebuie semnalat un ultim dezacord major între latiniști și romaniști. Dacă cei dintîi, în ciuda opozițiilor exprimate, pot accepta sintagma latină vulgară, în lucrările de romanistică și de istorie a limbilor neolatine este mai frecventă expresia latină populară. Îi datorăm tot lui E. Coșeriu observația decisiv lămuritoare cu privire la relația dintre denumirea și esența conceptului: „În general, conceptul de 'popor' (când nu e echivalent cu cel de 'colectivitate de vorbitori') este, în lingvistică, un concept ambiguu, ale cărui limite nu le cunoaște nimeni. Iar în cazul aşa-zisei „latine vulgare” este vorba, în plus, de o petitio principii, căci înseamnă să prezinți ca demonstrat ceea ce trebuie să fie demonstrat. Într-adevăr, un mod lingvistic oarecare nu este „popular” pentru că face parte din „latina vulgară” (care nu e altceva decât latina care a fost continuată fără întrerupere de limbile romanice), ci, dimpotrivă ,latina vulgară” este „populară” în măsura în care sînt „populare” modurile lingvistice care o compun. Însă așa ceva nu se poate admite anticipat, ci trebuie să fie dovedit pentru fiecare mod în parte" (Coșeriu, 1997, p. 154).

\section{Periodizare}

Avînd ca trăsătură specifică aspectul vorbit al limbii, latina vulgară este dificil de definit din punct de vedere cronologic, deoarece ea se poate identifica astfel cu însăşi limba latină, ca limbă vorbită în toate epocile existenței sale. De aici, impasul latinistului: „quand le faire intervenir? au tout début, sous l'Empire, au $\mathrm{V}^{\mathrm{e}}$ siècle, ou encore plus tard: $\mathrm{VI}^{\mathrm{e}}, \mathrm{VII}^{\mathrm{e}}, \mathrm{VIII}^{\mathrm{e}}$, siècle?" ${ }^{12}$ (Flobert, 2014, p. 437). Marea problemă pentru cercetător este că orice încercare de cronologizare, cu delimitări clare, se face doar pe baza atestărilor scrise. În acest caz, o cronologie a limbii latine se poate confunda cu o periodizare a limbii literaturii latine, în sensul larg al cuvîntului.

În celebra Introduction au latin vulgaire, Veikko Väänänen delimitează, pe baza surselor scrise (v. Väänänen, 1981, p. 11-13), mai multe etape în dezvoltarea latinei, dar care se confundă mai curînd cu istoria latinilor şi cu istoria literaturii latine:

I. Latina arhaică: de la origini la sfirșitul secolului al II-lea a.C.;

II. Latina preclasică: de la sfîrșitul secolului al II-lea pînă la mijlocul secolului I a.C.;

III. Latina clasică („vîrsta de aur”): de la mijlocul secolului I a.C. la moartea lui Augustus (14 p.C.);

IV. Latina postclasică („,îrsta de argint”): de la moartea lui Augustus pînă în jur de anul 200.

V. Latina tîrzie (numită și bas latin): din jur de 200 pînă la apariția limbilor romanice.

În ce privește ultima perioadă, remarcăm că este văzută ca un tot unitar, probabil din cauza apariției și expansiunii literaturii latine creștine.

O periodizare a limbii latine, concentrată asupra epocii tîrzii, epoca de tranziţie spre limbile romanice, este concepută în trei etape istorice de către Coșeriu (1954). Redăm această cronologie făcînd o seamă de observații privitoare la raportul dintre limba scrisă a epocii cu latina clasică și cu cea vorbită:

a. „Pînă în secolul al III-lea p.C.: Latina clasică și vulgară nu sînt prea diferite. Se poate vorbi de o singură limbă, cu două variante”.

[Pentru el, latină vulgară și latină clasică constituie două niveluri ale aceluiași continuum, astfel încît latina vulgară este toată latina care se dezvoltă și se îndepărtează de latina fixată, adică de latina literară, latină care nu se desfășoară în acord cu limba vorbită.] (Coșeriu, 2005, p. 25, nota 12).

${ }^{12}$ „[...] cînd să accepți că intervine? chiar la început, în timpul Imperiului, în secolul al V-lea sau încă mai tîrziu: în secolul al VI-lea, al VII-lea, al VIII-lea?" 
Deși coincide cu apariția și răspîndirea creștinismului, nu este încă latina scrierilor creștine. Cele mai vechi traduceri biblice din corpusul Vetus latina pot fi datate în secolul al II-lea, însă e vorba de încercări fragmentare de traducere din greacă, iar primul mare scriitor creștin de limbă latină, Tertullianus (155-240), își începe activitatea spre sfirșitul secolului al II-lea.

Este de remarcat faptul că această perioadă coincide cu cucerirea Daciei și cu primul secol de stăpînire romană. Altfel spus, finalul acestui lung interval din istoria latinei cuprinde o parte esențială a procesului de romanizare, în special în nordul Dunării. Această limbă unitară, cu variante foarte apropiate, reprezintă stadiul latinei aduse de armată și de coloniștii romani, care se află la baza procesului de romanizare. Acesteia i se adaugă elementele autohtone într-o continuă diminuare de la o generație la alta.

b. „Începînd din sec. al III-lea și al IV-lea p.C.: diferenţele se accentuează și devin mai importante, putîndu-se considera că există două limbi distincte: latina literară și latina vorbită sau curentă”.

Este secolul în care creștinismul devine religia oficială a Imperiului Roman. Cum poate fi ilustrată limba literară din această perioadă în care apar scrierile celor mai reprezentativi autori latini creștini? Prin mentalitatea lor determinată de un nou tip de spiritualitate, în acord cu textul biblic, care acționează ca model, și cu nevoia de înțelegere a tuturor creștinilor, indiferent de nivelul social, acești autori contribuie, în scris, la unitatea latinei. Atît oral (ca predicatori), cît și în scris (ca autori ai unei teologii creștine), aceștia își propun să se adreseze oricărui tip de ascultător sau cititor. Prin urmare, latina creștină este mai puțin relevantă din perspectiva opoziției scris vs. vorbit și limbă cultă vs. limbă populară. Ea intră în opoziție cu latina precreștină, a cărei continuatoare este în mod firesc, cu modificări, în primul rînd lexicale (în urma împrumuturilor limitate din greacă și ebraică) și semantice (prin atribuirea sau schimbarea sensurilor unor cuvinte, conform noii religii).

Aceasta este latina ultimelor șapte decenii de existență a Daciei ca provincie integrată în Imperiul Roman și a primelor generaţii de locuitori care pot fi consideraţi complet romanizaţi. În măsura în care latina s-a răspîndit în teritoriu, aceștia trăiesc într-un mediu cultural și lingvistic latin, avînd teoretic acces la toate resursele limbii din acea epocă. Din această perspectivă, nu sînt motive să credem că au fost operate selecții lexicale importante privitoare la vocabularul latinei ca instrument complex de comunicare la diferite niveluri.

c. „Pînă în secolul VI: Se poate spune despre latina vorbită că devine o limbă unică pînă în secolul VI”. Limba vorbită, fără a fi fundamental diferită de limba scrisă a epocii respective, caracterizează diferitele forme de comunicare. Considerat a fi ultimul mare scriitor creștin din perioada tîrzie, papa Gregorius Magnus (540-604) este cunoscut în special pentru ciclul de Dialoguri, scrieri adresate maselor de cititori, cu un mare succes în epocă. Textele, foarte populare şi accesibile, nu sînt scrise într-o latină „populară”. Lexicul, în măsura în care nu exprimă realități creștine, este unul comun, care poate fi atestat în diverse epoci ale latinei.

Într-un teritoriu rămas în afara continuumului latin, cum este cazul Daciei, este de presupus că tendințele de evoluție separată devin tot mai intense. Lipsită de influența teologică și lingvistică unificatoare, asigurate de organizarea ecleziastică a Bisericii Apusene, acest spațiu nu poate cunoaște decît tendințe centrifuge. În Occident se conturase deja un mod de viață creștin prin traducerea integrală a Bibliei în latină, prin exegeza acesteia în texte care dobîndiseră autoritate, prin cicluri de omilii ale unor mari predicatori latini, păstrate și transmise în scris, prin organizarea vieții monastice, printr-o teologie și chiar printr-o literatură creștină. Acest model cultural unitar lipsea în nordul Dunării, iar retragerea administrației romane și decăderea aglomerațiilor de tip urban, ca centre de iradiere spre comunitățile mai mici, deschideau calea unor evoluții fără un tipar clar. Acestea se concretizau în special în inovații (la nivelul formei și sensului), precum și într-un proces de selecție a termenilor, care a dus la pierderea unei părți însemnate a vocabularului latin în română, asemenea celorlalte limbi romanice. 


\section{Relația dintre lexicul latinei vulgare și lexicul latinei clasice}

Cele mai importante lucrări de istorie a limbii române au cercetat în amănunt lexicul moștenit din latina vulgară, explicînd evoluția formelor (pe baza legilor fonetice), a sensurilor, interpretînd selecția termenilor în funcție de evenimentele istorice și de caracteristicile sociale, culturale etc. ale populaţiei romanizate.

Pornind de la ideea că acești termeni aparțineau limbii vorbite a oamenilor simpli, am considerat că numai o incursiune făcută, în fiecare caz în parte, în atestările cuvîntului în diferite epoci ale latinității poate arăta relaţia strînsă dintre latina clasică și latina vulgară. Observația Mariei Iliescu: „Il ne faut pas oublier non plus que toutes les formes et mots du latin littéraires ont une fois été des formes du latin courant, parlé [...]"13 (Iliescu, 2013, p. 142) stabilește cea mai firească legătură între cele două variante ale latinei prin intermediul lexicului. De asemenea, existența unui cuvînt în paralel în latina clasică și în ceea ce se numește latină vulgară din perioada tîrzie atestă apartenența lui la latina comună, care cunoaște atît aspectul vorbit, cît și cel scris. Acesta din urmă este continuat în primul rînd prin latina scrierilor creștine, ca formă a latinei literare din perioada tîrzie.

Pentru a putea concluziona că un termen nu este specific latinei vulgare, ci latinei comune, am stabilit două criterii:

a. să fie atestat în toate perioadele latinității (dacă apare în latina arhaică și în latina tîrzie, poate fi presupusă existența termenului în toate perioadele, deoarece e prea puțin probabil ca el să fi fost abandonat în vorbire pentru a fi reluat ulterior);

b. să fie atestat în literatura cultă din perioada clasică, dar și la marii autori ecleziastici, în special în tratate (scrieri cu un nivel de limbă superior și cu un nivel de oralitate mai redus decît al predicilor, omiliilor şi epistolelor).

Am verificat, pe baza contextelor, evoluția sensurilor cuvintelor în cele trei mari perioade (arhaică, clasică, tîrzie) pentru a observa eventualele inovații semantice din perioada tîrzie sau la autori ale căror opere sînt recunoscute pentru faptul că cuprind vulgarisme (de ex. Plautus, Terentius, Petronius, Apuleius) în comparație cu autorii consideraţi clasici (Vergilius, Lucretius, Horatius, Ovidius etc.).

Dat fiind spațiul limitat, am operat o selecție aleatorie, dar nu întîmplătoare, a unui număr de 11 termeni latini. Atestarea lor nu s-a limitat la articolele de dicționar respective, ci a fost extinsă la o cît mai mare varietate. Acest lucru a fost posibil datorită mijloacelor moderne de investigare a literaturii latine (corpusul de texte publicat de Brepols: CLTCLT-5).

\section{1. $\boldsymbol{C A S A}$ (panr.)}

Este unul din termenii care denotă o realitate lingvistică din lumea oamenilor simpli și săraci. Se pune intrebarea dacă, din acest motiv, trebuie considerat că și cuvîntul în sine aparține exclusiv unui nivel de limbă vorbită, inferior latinei clasice.

Termenul nu este atestat la Plautus, însă apare la Terentius (sec. II a.C.) într-un proverb în care casa are deja sensul general de 'casă': Ita fugias ne proter casam (Phormio 768) ,astfel să fugi, încît [să nu treci] prin faţa casei”' ${ }^{4}$. Ceea ce pentru oamenii simpli este 'casă, în general, pentru cei care aparțin unor niveluri sociale superioare, înseamnă 'colibă, locuință sărăcăcioasă. Superior, Quintilianus arată binefacerile progresului uman, fără de care n-ar fi fost necesar ca domibus quidem casas aut vestibus pellium tegmina aut urbibus montes ac silvas mutari (Institutio oratoria 9, 4, 4) „colibele să fie schimbate cu case, pieile de animal, cu haine, munții și pădurile, cu orașe”. Termenul apare la autori clasici cunoscuți, atitudinea lor fiind atît de respingere, cît și de simpatie, în funcție de context.

Vergilius (Bucolica 2, 28) asociază humiles casas „micile colibe” cu sordida rura „murdăria de la țară”. Pentru Lucretius (De rerum natura 6, 1254), casa este locul în care își găsesc sfîrșitul, din cauza bolii

\footnotetext{
${ }_{3}^{13}, \mathrm{Nu}$ trebuie uitat nici faptul că toate formele și cuvintele latinei literare au fost odată forme ale latinei curente, vorbite [...]".

${ }^{14} \mathrm{Cf}$, „Si tu es en fuite, ne passe pas devant la maison” (trad. Marouzeau, 1990, CUF).
} 
și a sărăciei, păstorul, văcarul și plugarul. În Elegie, Propertius folosește termenul de cinci ori, cu sens depreciativ, evidențiat de determinant: immunda casa $(2,23,9)$,colibă murdară”, sine arte casa $(4,1,5)$ „o colibă (făcută) fără îndemînare”, putris casa $(4,9,28)$,o colibă în ruină”, summota casa $(5,9,56)$,o colibă îndepărtată". Pentru Ovidius (17 oc.) casa e și coliba e ramis frondea facta (Fasti 3,527$)$ „făcută din ramuri, acoperită cu tufe", dar și coliba de la începuturile Romei, cînd poporul era sărac, însă: dum casa Martigenam capiebat parua Quirinum (Festi 1, 199) „cînd o colibă mică îl adăpostea pe Quirinus, fiul lui Marte", pentru că: hic, ubi nunc Roma est, orbis caput, arbor et herbe / et pauca pecudes et casa rara fuit (Fasti 5, 93-94) „aici, unde e acum Roma, capitala lumii, au fost copaci, iarbă / puține turme și cîteva colibe".

Cicero ( 5 oc.) povestește că a fost în casas aratorum, a stiva ipsa homines mecum colloquebantur (Pro M. Emilio Scauro oratio 25, 1) „colibele unor plugari care vorbeau cu el chiar de la coarnele plugului”, dar şi că însuşi Ptolemeu, în Egipt, cibarius in casa panis datus esset (Tusculane disputationes 5, 34, 97) ,într-o colibă i s-ar fi dat pîine neagră”, și că nimic nu i s-a părut mai plăcut decît acea pîine.

Aflăm și de la Titus Livius cui îi erau specifice acest tip de locuințe. Autorul se întreabă dacă: non in casis ritu pastorum agrestiumque habitare est satius? (Ab Urbe condita 5, 53,7) „n-ar fi mai bine să locuim în colibe, după obiceiul păstorilor și al țăranilor?”.

În secolul II p.C., se observă o schimbare la Apuleius (Metamorphoses 3, 29), care vorbește de casas amplas „locuințe spațioase”, în opoziție cu uillulas „căsuțe”.

$\mathrm{Cu}$ o singură atestare în textul biblic (Liber sapientice $\left.{ }^{15} 11,2\right)$ : in locis secretis fixerunt casas ,s, și-au înfipt corturile în locuri nemaiumblate" (Septuaginta IV/2, p. 203), termenul nu poate fi considerat specific literaturii creștine. Blaise (1993, s.v. casa) îl semnalează la autori tîrzii cu sensul de 'domeniu, fermă, proprietate', dar și de 'lupanar', însă atestările sînt reduse ca număr.

Tertullianus (Aduersus Iudaos 3, 23) și Cyprianus (Ad Qurinum 1, 6, 3), citînd din Isaias, 1, 8, folosesc sicut casa in uinea "ca o colibă într-o vie”, acolo unde Hieronymus va traduce, în Vulgata, cu sicut umbraculum in vinea „ca un cort de frunze într-o vie”. La Ambrosius, apare sintagma pastorales casas „colibe de păstori” (Expositio euangelii secundum Lucam 7, 465; Epistule 10,73, 30), iar la Augustinus: casas in uicis „case în sate” (Enarrationes in Psalmos 80, 2; 80, 17).

În sfîrșit, cuvîntul poate primi un sens mult mai important în exegeza creștină: tabernaculum autem illud, id est casa ubi Abraham pro tempore manebat, figura erat ciuitatis Ierusalem in qua <pro> tempore lex et prophete, ipse quoque dominus et apostoli habitauerunt [...] (Gregorius Illiberitanus, Tractatus Origenis de libris Sanctarum Scriptarum 2, 63) „Cortul acela, adică coliba unde Avram după împrejurări rămînea, era imaginea cetăţii Ierusalim în care, după împrejurări, au locuit legea și profeții, chiar însuși Domnul și apostolii".

În concluzie, observăm că termenul casa denotă o realitate comună unei largi clase sociale de la baza societății romane. Termenul s-a păstrat în toate epocile, fără a cunoaște o evoluție semantică notabilă. Păstrarea lui în limbile romanice trebuie pusă în legătură cu perpetuarea unui mod de viață rural. Credem că decăderea vieții orășenești în imperiu (cf. Ivănescu, 2000, p. 172) nu a dus automat la generalizarea lui casa, ci, mai curînd, la dispariția treptată a termenului domus.

\subsection{PAVIMENTUM ${ }^{16}$}

Sensul de bază al lui pavimentum, -i este de 'pămînt bătătorit', fiind un deverbal de la pavio, -ire, -ivi, -itum 'a bătători (pămîntul), a nivela', sensul substantivului evoluînd, prin specializare, la 'pardoseală cu lespezi sau mozaic, pavaj. Cu sensul inițial, pavimentum e pămîntul bătătorit din interiorul casei sau din preajma ei (vezi bătătură). În locuințele bogate, acesta e reprezentat de lespezi, în timp ce în casele simple, e doar pămînt bătătorit. Există informații precise despre modul în care a evoluat tehnica pavajului

\footnotetext{
${ }^{15}$ Cartea înțelepciunii lui Solomon.

${ }^{16}$ „Astfel pavimentum 'teren pavat, pardosit', 'pavaj', 'mozaic', a ajuns să însemneze 'pămînt”' (Ivănescu, 2000, p. 174-175). Este considerată o evoluție semantică „numai în latina populară din Dacia, și anume din cauza rusticizării vieții” (Ivănescu, 2000, p. 174).
} 
la Cato, De agricultura 18, 7, la Vitruvius, De architectura 7, 1, 1-5 sau Plinius Maior, Naturalis historia 36,185 , autor care stabilește legătura dintre originea cuvîntului și un vechi obicei din Italia ${ }^{17}$, folosit în casele oamenilor simpli.

Cu sensul de 'pămînt' (Blaise, 1993, s.v. pauimentum: „le sol”), 'țărînă'18, termenul apare și în Vulgata, Num, 5, 17: adsumetque aquam sanctam in vase fictili et pauxillum terre de pavimento tabernaculi mittet in eam „apoi va lua preotul apă vie, curată, într-un vas de lut, va lua țărână din pământul de dinaintea cortului mărturiei” (Anania, 2001, p. 162); „și să ia preotul apă curată, vie, într-un vas de lut și țărână din bătătura cortului mărturiei" (Septuaginta I, p. 442) și Ps, 118, 25: adhesit pavimento anima mea „Sufletul mi s’a lipit de pământ” (Anania, 2001, p. 755); „Lipitu-s-a de țărână sufletul meu” (Septuaginta IV, p. 292). Acestui pasaj, Ambrosius îi dă o explicaţie concludentă: per pauimentum terram intellegimus, per terram materialia (Expositio psalmi 118, 4,2) „prin pauimentum înțelegem pămînt, prin pămînt, cele materiale".

În concluzie, termenul este atestat încă din sec. II, a.C., cu sensul de bază la Cato (De agri cultura) și cu sensuri particularizate, în funcție de context, la majoritatea autorilor latini precreștini (Horatius, Cæasar, Cicero, Seneca etc.). Sensurile actualizate corespund unor realităţi extralingvistice diverse. În română, sensul generalizat de 'sol' nu e necesar să fie rodul unei evoluții ulterioare, de vreme ce acesta este atestat atît la autorii precreștini, cît și în latina tîrzie, creștină.

\subsection{CABALLUS (panr.)}

Termenul nu are multe atestări în latină, dar apare în toate epocile. În perioada veche (sec. II a.C.), e atestat la Lucilius (sec. II, a.C), Saturarum fragmenta (in aliis scriptis seruata), v. 163, într-un context depreciativ: succusatoris, tetri tardique caballi, fiind vorba despre „calul care te scutură, urît și lent”. Este calul ogorului, calul jugănit, care trage și cară poveri. Cu acest sens, intră în opoziție cu equus, -i, calul pentru călărie și pentru cavalerie. Între cei doi termeni este o opoziție funcțională care se menține în toate epocile. Cu toate acestea, caballus, asemenea lui equus, poate primi și sensul general de 'cal', contextul fiind mai mult sau mai puțin explicit: Quid, uos, inquit? iumentum me putatis esse aut lapidariam nauem? Hominis operas locaui, non caballi. (Petronius 117) „Ce, spune, mă credeți animal de povară sau corabie de cărat pietre? M-am angajat să fac muncile unui om, nu ale unui cal.”; O quantum erat seculi decus, imperatorem triumphalem, censorium, quod super omnia hac est, Catonem uno caballo esse contentum et ne toto quidem. Partem menim sarcine ab utroque latere dependentes occupabant. (Seneca, Epistule morales ad Lucilium 87, 10) „O, cît de mare era gloria vremii, cînd un împărat triumfător, fost cenzor, mai presus de toate, un Cato se mulțumea cu un cal care nici măcar nu era numai pentru el. Bagajele, care atîrnau de ambele laturi, ocupau o parte.”.

Caballus poate fi la Horatius, autorul cu cele mai multe ocurențe ale acestui termen ( 5 oc.), calul de la țară al unui bogat proprietar de domenii întinse: [...] non ego me claro natum patre, non ego circum / me Satureiano uectari rura caballo, $[. .$.$] (Sature 1,6,56)$ „[...] nu spun că m-am născut dintr-un tată vestit, nici că am fost purtat în jurul proprietăților mele de un cal tarentin.”.

În perioada tîrzie, caballus este atestat în mari texte ale literaturii creștine: dicebat [...] caballum se scilicet factum annonam inter alia iumenta baiulasse militibus [...] (Augustinus, De ciuitate Dei 18, 18, 52) „zicea [...] că a fost transformat în cal și că a cărat alimente pentru soldaţi, alături de alte animale de povară [...]”. Folosit de soldați pentru a căra bagajele și alimentele, caballus este văzut depreciativ în comparație cu equus, însă contextul este cel care dă acest sens cuvîntului: [...] et non intellegimus prophetarum uoces: fugient mille uno persequente nec amputamus causas morbi, ut morbus pariter auferatur, statimque cernimus sagittas pilis, tiaras galeis, caballos equis cedere? (Hieronymus, Epistuale 60, 17) „[...] și nu înțelegem cuvintele profetului: «o mie vor fugi de unul care îi urmărește» și nu retezăm cauzele bolii, ca și boala să fie îndepărtată, și să vedem îndată săgețile cedînd în fața sulițelor, tiarele, în fața coifurilor, mîrțoagele ${ }^{19}$,

\footnotetext{
${ }^{17}$ Pavimenta credo primum facta que nunc vocamus barbarica atque subtegulanea, in Italia festucis pavita "Je crois que les premiers pavements effectués furent ceux que nous appelons à présent barbares et pavements sous couvert. Ces sols battus furent en Italie faits à l'aide de hies, c'est ce qui du moins peut s'entendre du nom même." (trad. Bloch, 1981, CUf).

${ }^{18}$ Cf. pavimentum stratum lapide "pămînt acoperit cu piatră” (Iez, 40, 17).

${ }^{19}$ De fapt, „caii de povară”.
} 
în fața cailor ${ }^{20}[\ldots] ”$.

Putem concluziona că termenul caballus, existent în toate perioadele latinității, fiind atestat la autorii culți, nu este un cuvînt din latina vulgară, ci denumește o realitate extralingvistică, caracteristică în primul rînd lumii rurale, dar și celei militare. Asemenea tuturor animalelor care au rolul de a căra (boul, măgarul), poate primi conotații depreciative, rămînînd, însă, o ființă indispensabilă.

\subsection{FORMOSUS (rom., it., prov., sp., port.)}

Prima atestare a cuvîntului e la Plautus, pentru a caracteriza un animal: Mercari uisus mihi sum formosam capram (Mercator 229) „Mi s-a arătat că am cumpărat o capră frumoasă”21. Tot în perioada arhaică găsim: virginem formosam (Titinius, Comoediarum fragmenta 18) „fecioară frumoasă” și formosus homo (Lucilius, Saturarum fragmenta 418) „bărbat frumos”.

În perioada clasică, Propertius folosește cu precădere cuvîntul în Elegie, într-o varietate de asociaţii, care merg de la concret la abstract: humus formosa $(1,2,9)$ "pămînt frumos”, formosi temporis atas $(1,4$, 7 ) „perioada vremurilor frumoase”, formosa Doride $(1,17,25)$,frumoasa Doris ${ }^{22}$, formosos pedes $(1,18$, 10) "picioare frumoase", formosa heroine $(1,19,13)$,frumoasele eroine" etc. ${ }^{23}$. Cu valoare de substantiv sau de adjectiv, Ovidius folosește termenul în aproape toate scrierile sale: Amores (21 oc.), Ars amatoria (9 oc.), Epistula ex Ponto (1 oc.), Fasti ( 9 oc.), Heroides (13 oc.), Metamorphoses (23 oc.), Remedia amoris (4 oc.), Tristia (1 oc.). În majoritatea cazurilor, autorul folosește apreciativ adjectivul feminin, în sintagma: formosa puella „tînără frumoasă”, însă întrebuințarea termenului este variată: Non formosus erat, sed erat facundus, Ulixes (Ars amatoria 2, 123) „Ulise nu era frumos, dar era meșter la vorbă”; formosissimus annus (Ars amatoria 2, 315) „anul e foarte frumos”; formosa manu (Ex Ponto 1, 10, 12) „cu mîna frumoasă”; formosa Venus formoso tempore digna est (Fasti 4, 129) „,frumoasa Venus merită un anotimp frumos” etc. Horatius (3 oc.) folosește sintagma mulier formosa (De arte poetica 4 ) „,femeie frumoasă”. Termenul este curent și la Cicero (17 oc.), care mărturisește într-una din scrisori că: nibil est enim, mibi crede, virtute formosius, nibil pulchrius, nibil amabilius (Cicero, Epistula ad familiares 9, 14, 4) „Crede-mă, nimic nu e mai frumos, mai demn de laudă, mai demn de iubit decît virtutea”.

Deși nu apare în textul biblic, formosus e curent la Augustinus (42 oc. atît în tratate, cît și în predici) și la Hieronymus (33 oc.). Cu sens figurat, care exclude orice interpretare legată de frumusețea formelor, îl găsim la Augustinus: [...] illa pre cunctis formosa et luminosa ueritas tua. (Confessionum libri tredecim $2,6,23),[. .$.$] Dreptatea ^{24}$ ta mai frumoasă și mai luminoasă decît toate”; anima [...] formosa (De ordine $1,8,71)$,sufletului [...] frumos” etc.

Considerînd, probabil, că termenul nu dezvoltă un sens cu adevărat special în literatura creștină, Albert Blaise nu îi dedică un articol în Dictionnaire latin-français des auteurs chrétiens, ceea ce ar însemna că formosus s-a păstrat în latina tîrzie cu sensurile atestate în latina arhaică, continuate și în scrierile clasice.

\subsection{VETULUS (panr.)}

Considerat, ca formă, diminutivul adjectivului vetus, -eris (opusul lui nouus), termenul are în latina clasică sensul de 'vechi', aplicat atît oamenilor, cît și animalelor și plantelor. Adjectivul apare adesea substantivat: uetulus, $-i$,un bătrîn” și uetula, $-\mathfrak{\alpha}$ „o bătrînă”. Este un cuvînt mai puțin folosit, însă atestat în toate perioadele latinității.

La Plaut (10 oc.), opoziția senex (cu referire la stăpîn) vs. uetula (referitor la o oaie) nu are decît cel mult valoare stilistică în pasajul: Mi senex, tam uetulam? (Mercator 525) „Așa bătrînă, moșule?”.

\footnotetext{
${ }^{20}$ "Caii de luptă”.

${ }^{21}$ „Une chèvre de toute beauté." (trad. Ernout, 1992, CUF).

${ }^{22}$ Fiica lui Okeanos, mama Nereidelor.

${ }^{23}$ Vezi aparenta opoziție formosa vs. pulchra (Propertius, Elegia 2, 28, 49): sunt apud infernos tot milia formosarum: / pulchra sit in superis, si licet, una locis! „Il y a dans les lieux infernaux tant de miliers de belles: qu'il y ait une beauté, s'il est permis, dans ceux d'en haut!" (trad. Viarre, 2005, CUF).

${ }^{24}$ „Adevărul”.
} 
La Lucretius găsim: tristis uetula uitis sator (De rerum natura 2, 1168) ,tristul plantator al unei vii îmbătrînite”, iar Horatius (Carmina 3, 15, 16; 4, 13, 25) numește uetule „bătrîne” două personaje feminine din epocă, pe care le ironizează. Cicero $(5$ oc.) folosește termenul, în registre variate, pentru gladiatore uetulo (Pro P. Quinctio oratio 29, 16) "gladiator îmbătrînit (în secretele meseriei)", pentru uetuli equi (Lelius de amicitia 67, 6) „cai bătrîni”, în opoziție cu cei teneri „tineri”, pentru o femeie uetula sane et multarum nuptiarum (Epistula ad Atticum 13, 28, 4) "prea bătrînă și măritată de multe ori”, dar și ca apelativ prietenesc, indiferent de vîrstă: mi uetule (Epistule ad familiares 7, 16) „Bătrîne!”.

E firesc ca la Varro, în Res rustica, substantivele determinate de adjectivul uetulus, $-a$ „bătrîn, -ă” să desemneze catuli $(2,9,3)$ „cîini”, boues $(2,5,6)$ „boi”, columbe $(3,7,8)$ „porumbei”, galline $(3,9,9)$ „găini”.

Pentru a-l ironiza pe stăpînul fără gusturi, care nu știe să-și aleagă servitorii, Petronius folosește sintagma puer uetulus (Satyrica 28, 4, 11) „băiat bătrînicios”. Termenul este folosit des în epigramele lui Martialis (19 oc.) și în satirele lui Iuvenalis (7 oc.).

În literatura creștină, termenul apare la un număr restrîns de autori, iar la Augustinus este atestat o singură dată (Contra Faustum 14, 15). Spre deosebire de el, Hieronymus îl folosește mai des (10 oc.), cu referire la uxor (Liber quastionum hebraicarum in Genesim 39, 4) „soție" ${ }^{25}$, uirgo (Commentarii in Isaiam 3, 7, 14) „fecioară”, mulieres (Commentarii in IV Epistulas paulinas, Ad Titum 613) „femei” etc. Același autor dă o explicație lămuritoare pentru valoarea funcțională a cuvîntului: caueant ergo, ut diximus, tam iuuenes quam senes, tam adolescentule quam uetula (Commentarii in IV Epistulaspaulinas, Ad Titum 614) „să se păzească, cum am spus, atît tinerele, cît și bătrînele, atît fetele tinerele, cît și bătrînicile”.

În Vulgata, cuvîntul e folosit doar de două ori: dominus meus vetulus est (Gen, 18, 12) „stăpînul meu e bătrîn” și: ante eritis vetula (Ruth, 1, 13) ,înainte veți fi bătrîne”.

Fără a fi frecvent, cuvîntul este atestat de-a lungul epocilor literaturii latine, fără a se observa o evoluție a sensului nici măcar în context creștin. Este de remarcat că nu am putut releva niciun exemplu în care adjectivul uetulus, -a să determine un substantiv nume de obiect.

\subsection{AURICULA (rom., it., retr., fr., sp., port.)}

Deși, formal, este diminutivul de la auris, auricula are un sens specializat „partea externă a urechii, lobul" (Gaffiot, 2000, s.v. auricula) ${ }^{26}$, deci partea vizibilă a urechii, asociată cel mai adesea cu organul în ansamblul său. $\mathrm{Cu}$ acest sens, termenul este folosit atît în latina arhaică, la Plautus: Sine te exorem, sine prehendam auriculis, sine dem sauium. (Pcenulus 374) „Lasă-mă să te înduplec cu rugăminți, lasă-mă să te prind de urechi, lasă-mă să-ți dau un sărut.", cît și în latina clasică, la Cicero: [...] auriculam fortasse mordicus abstulisset [...] (Epistule ad Quintum fratrem 3, 4, 2, 3 ) „[...] probabil mi-ar fi smuls urechea mușcînd-o cu dinții [...]”. Nici cuvîntul în sine, nici partea corpului pe care o desemnează nu implică ideea de vulgaritate. Dimpotrivă, auricula este sinonim cu auris la Plinius Maior, de la care aflăm că: est in aure ima memorie locus, quem tangentes antestamur; (Naturalis historia 11,251) „locul memoriei se află în partea cea mai de jos a urechii, pe care, atingînd-o, depunem mărturie”. Obiceiul este amintit de Horatius: [...] oppono auriculam. (Sature 1, 9, 75) „[...] îmi întind urechea” (ca gest la cererea de a fi martorul cuiva).

Chiar din punct de vedere medical, auricula este sinonim cu auris la Celsus care, printre alte boli din timpul verii, enumeră și auricularum dolores (De medicina 2,1 ) „durerile de urechi”.

Între poeții secolului I a.C., la care este atestat termenul, mai pot fi citați Lucretius, De rerum natura 4, 592; Propertius, Elegie 1, 16, 27; Catullus, Carmina 67, 41.

În creștinism, auricula păstrează sensul clasic de „ureche” și devine frecvent în tratatele și în predicile autorilor ecleziastici, datorită, în bună măsură, a două pasaje celebre din textului biblic (din cele 19 ocurențe): sumes de sanguine ipsius et pones super extremum dextre auricula Aaron [...] (Exodus, 29, 20) „Să iei din sîngele lui și să pui pe lobul urechii drepte a lui Aaron [...]” (îi poruncește Dumnezeu lui Moise) și: et ecce unus ex his qui erant cum Iesu extendens manum exemit gladium suum et percutiens servum principis

\footnotetext{
${ }^{25}$ Se face trimitere la Facerea, cap. 18.

${ }^{26}$ „Oreille [considérée dans sa partie externe]”.
} 
sacerdotum amputavit auriculam eius (Euang. sec. Matthaum, 26, 51) „,̧i iată, unul dintre cei ce erau cu Iisus, întinzînd mîna a tras sabia și, lovind pe sluga arhiereului, i-a tăiat urechea”.

Dintre autorii creștini, îi amintim pe: Tertullianus, De pudicitia 13, 61; Lactantius, De mortibus persecutorum 36, 7, 28; Arnobius, Aduersus nationes 1, 52, 1 ș.a.; Ambrosius, Expositio enangelii secundum Lucam 7, 852 ș.a.; Paulinus Nolanus, Epistuale 49, 14, 24; Augustinus, In Iohannis euangelium tractatus 102, 4, 26 ș.a.; Hieronymus, Aduersus Iouinianum 2, 25, 5 etc.

Frecvența termenului în scrierile clasice și tîrzii, cu sens precis și generalizat, ne permite să constatăm apartenența lui la fondul comun al limbii latine.

\section{7. $\boldsymbol{G U L} \boldsymbol{A}$ (panr.)}

La Plautus, în aceeași comedie, cuvîntul are sensurile de 'gură': follem obstringit ob gulam [...] ne quid anime forte amittat dormiens (Aulularia 302) ,își leagă strîns o pungă din piele la gură [...] nu cumva să piardă ceva din suflu cînd doarme" și 'gît': Ibo intro atque illi socienno tuo iam interstringam gulam (Aulularia 659) „Voi merge înăuntru și pe loc am să-l strîng de gît pe tovarășul acela al tău”.

Ovidius folosește metafora flamma gulde (Metamorphoses 8, 845-846) pentru a reda „pofta lăcomiei”, iar Horatius face o comparație hiperbolică Harpyiis gula digna rapacibus (Sature 2, 2, 39) „o gură demnă de lacomele harpii”. A rămas celebră exclamația depreciativă a lui Cicero: O gulam insulsam! Pudet me patris. (Epistula ad Atticum 13, 31, 4) „Ce om fără gust ${ }^{27}$ ! Mi-e rușine pentru tatăl lui!”.

Termenul este curent, fiind atestat la unii dintre cei mai cunoscuți scriitori antici: Varro, Sallustius, Seneca, Petronius, Martialis, Iuuenalis, Tacitus, Plinius Maior, Aulus Gellius, Apuleius. Majoritatea ocurențelor se găsesc la autorii creștini: Tertullianus ${ }^{28}$, Lactantius, Ambrosius, Eusebius Cæasariensis, Paulinus Nolanus, la Augustinus, în predici, tratate, chiar și în Confessionum libri tredecim 1, 19, 10, unde autorul mărturisește cum comitea furturi din lăcomie: gula imperitante ${ }^{29}$, Iohannes Cassianus, Hieronymus ș.a., însă cuvîntul nu e atestat în Biblie.

Deși este folosit, în general, în contexte negative, depreciative, termenul gula nu aparține doar limbajului oamenilor inculți. El poate fi atribuit atît sclavului, cît și stăpînului, făcînd adesea trimitere la o trăsătură de caracter: lăcomia.

\subsection{BUCCA (panr.)}

Plautus folosește termenul cu mai multe ocazii, sensul fiind fără echivoc în: Age, iam infla buccas [...] (Stichus 767) „Hai, acum umflă-ți obrajii [...]”.

La Cicero, alături de sensul concret de „obraji”: Gallum [... e eiecta lingua, fuentibus buccis (De oratore 2, 266, 12) „un gal cu limba scoasă și cu obrajii atîrnînd”, apare și sensul figurat de „gură”, în expresia repetată în finalul scrisorilor: si rem nullam habebis, quod in buccam venerit scribito (Epistule ad Atticum $1,12,4)$ „dacă nu ai nicio veste, scrie-mi ce-ți vine pe limbă $\breve{~}^{30}$.

Petronius folosește de trei ori cuvîntul, cu trei sensuri diferite: 'îmbucătură': non mehercules hodie buccam panis invenire potui (Satyrica 44, 2, 24) „pe Hercule, azi n-am putut găsi o gură de pîine”; 'obraz': ut mucronem ad buccam probaremus (Satyrica 70, 3, 16) „să încercăm tăișul [cuțitului] pe obraz”; 'gură, cu sens figurat, în expresia: dure bucca fuit, linguosus [...] (Satyrica 43, 3, 25) ,a fost tare ${ }^{31}$ de gură, guraliv $[\ldots]$...

Tot în secolul I p.C., într-o scriere cu caracter științific, Plinius Maior folosește același termen atît cu sensul de 'gură': quibus gene non sint, de malis, de naribus, buccis, labris, mento, maxillis de dentibus que genera eorum (Naturalis historia 1, 1, 45) „[animale] care n-au obraji, despre fălci, despre nări, [despre] gură, buze, bărbie, maxilare, despre dinți [...]”, cît și cu cel foarte clar indicat, de 'pliu, gropiță din obraji':

\footnotetext{
${ }^{27}$ Literal: „Ce gură nesărată!".

${ }^{28} \mathrm{Cu}$ sens metaforic: temporum gula, Res. 4 „la gueule du temps (qui engloutit les vivants)” (Blaise, 1993, s.v. gula).

${ }^{29}$ Literal: „Poruncindu-i gura”.

${ }^{30}$ "ce-ți trece prin cap".

31 „Rău”.
} 
Infra eas hilaritatem risumque indicantes bucce [...] (Naturalis historia 11, 158, 10) „sub acestea sînt obrajii care arată veselia și rîsul”.

Cuvîntul mai apare și la Cato, Origines 7, 5, 8 (citat de Aulus Gellius, Noctes attice 2, 22, 29 și de Apuleius, De mundo 14, 3), Suetonius, De grammaticis et rhetoribus 29, 1, 15.

În perioada creștină, îl întîlnim des la Augustinus, de exemplu în Confessionum libri tredecim 4, 16, 1, cînd îl evocă pe profesorul lui, retorul din Cartagina, care cita din Aristotel, „cu obrajii umflați de mîndrie" (buccis typho crepantibus) și în Epistula 3, 5 25, unde folosește expresia întîlnită și la Cicero (quod in buccam uenerit). Aceeași expresie apare și la Hieronymus: dictare quodcumque in buccam uenerit (Commentarii in prophetas minores, In Abdiam 776) „să spună orice le vine la gură”. În aceeași lucrare, autorul folosește termenul și cu sensul de 'obraji': rubentes buccas (In Mich aam 1,313) „obraji înroșiți””

În Vulgata nu e atestat decît diminutivul buccella, cel mai adesea în sintagma buccella panis „o îmbucătură de pîine”, cu trimitere la pîinea euharistică.

Atestat în toate epocile și la autori culți, în diferite tipuri de scrieri, putem considera că termenul este curent, nefiind caracteristic latinei vulgare.

\subsection{MANDUCARE}

Substantivul manducus, $-i$ „Mîncăul” ${ }^{2}$, de la care s-a format verbul manducare 'a mesteca; a mînca', este atestat pentru prima oară la Plautus, Rudens 535, iar participiul manducatum e folosit de Varro pentru a spune că puii de porumbel trebuie hrăniţi cu manducato candido pane (Res rustice 3, 7,9) „pîine albă mestecată $^{33 ”}$ ". Verbul este folosit de Celsus (De medicina 4, 3, 13; 4, 4, 22; și 4, 11, 25) cu sensul de 'a mesteca', cu referire la boabele de muștar (sinapi) și la planta numită portulacă. În aceste contexte, termenul nu este un vulgarism, ci, dimpotrivă, într-o scriere specializată, este folosit cu un sens precis, autorul (sec. I a.C.-sec. I p.C.) fiind cunoscut ca medic și enciclopedist.

Sensul general de 'a mînca' apare, în perioada tîrzie, la Petronius. Cele două contexte sînt discuții purtate de oameni simpli, al căror mod de a vorbi se încadrează perfect în ceea ce putem numi latină vulgară: inueniemus quod manducemus pullum, oua (Satyrica 46, 2, 10) „vom găsi ce să mîncăm, un pui, ouă”; boues, quorum beneficio panem manducamus (Satyrica 56, 4, 27) „,boii, grație [muncii] cărora mîncăm pîinea”.

Surpriza vine de la un scriitor ca Suetonius (sec. I-II p.C.) care, povestind despre obiceiurile culinare ale lui Octavianus Augustus, folosește verbul manducare tocmai cînd citează dintr-o scrisoare a însuși împăratului: et rursus: ne Iudeus quidem, mi Tiberi, tam diligenter sabbatis ieiunium seruat quam ego hodie seruaui, qui in balineo demum post horam primam noctis duas buccas manducaui prius quam ungui inciperem. (De uita Cesarum, Diuus Augustus 76, 2, 8) „,si în altă parte: «Dragul meu Tiberius, Nici măcar un evreu nu respectă cu atîta grijă postul cum am făcut azi eu care doar la baie, după prima oră a nopții, am luat două guri ${ }^{34}$ înainte să înceapă să mă dea cu unsori»”. Deși autorul spune mai sus despre împărat că „la mîncare era foarte reținut și aproape vulgar” (cibi minimi erat atque uulgarisfere), nu putem concluziona acelaşi lucru despre modul său de a vorbi și de a se exprima. Manducare aparține aici în mod clar limbajului familiar, des întîlnit în stilul epistolar al marilor autori.

Verbul devine cu adevărat curent în literatura creștină (la Tertullianus, Augustinus, Hieronymus etc.), un motiv foarte important fiind folosirea lui frecventă în textul biblic (în jur de 180 de ocurențe), în majoritatea cazurilor cu sensul de 'a mînca', subliniat de opoziţia cu verbul bibere 'a bea': venit Filius hominis manducans et bibens et dicunt ecce homo vorax et potator vini [...] (Vulg, Mat, 11, 19) „A venit Fiul Omului mîncînd și bînd, și spun: Iată om mîncăcios și băutor de vin [...]” (Anania, 2001, p. 1473). Cu toate acestea, sensul inițial de „a mesteca, a zdrobi cu dinții” este evident în unele contexte: in illo tempore abiit Iesus sabbato per sata discipuli autem eius esurientes coperunt vellere spicas et manducare (Vulg, Mat, $12,1)$ „În vremea aceea mergea Iisus printre holde într'o zi de sîmbătă, iar ucenicii Săi au flămînzit și au

\footnotetext{
${ }^{32}$ Personaj antic reprezentat printr-o față cu o gură mare.

${ }_{33}^{33}$ „Mărunțită".

${ }^{34}$ "Am mîncat pe fugă".
} 
început să smulgă spice și să mănînce” (Anania, 2001, p. 1473). Mestecarea boabelor de grîu poate fi pusă în relație cu cea a grăunțelor de muștar din exemplul de la Celsus (v. supra).

În concluzie, sensul clasic de 'a mesteca' și cel postclasic de 'a mînca' sînt atestate, ambele, în perioada tîrzie, în marea literatură creștină. E posibil ca tocmai folosirea lui frecventă în textul biblic să fi avut un rol important în păstrarea şi generalizarea acestui verb.

\subsection{INCENDERE (rom., it., retr., prov., cat., sp., port.)}

Derivatul prefixat al lui candere este sinonim aproape perfect cu accendere (cf. Ivănescu, 2000, p. 173), avînd în comun sensurile: 'a da foc, a aprinde, a arde; (fig.) a înflăcăra, a aprinde, a ațîța' (Gaffiot, 2000, s.v. incendo și accendo: 'allumer, embraser, (fig.) enflammer'). Chiar și cu sens metaforic, cele două cuvinte sînt permutabile la un cunoscător al limbii precum Cicero: luna incensa radiis solis ${ }^{35}$ (De natura deorum 1,87 ) și: luna radiis solis accensa ${ }^{36}$ (De re publica 6,17 ) pentru „luna luminată de razele soarelui”.

Frecvența verbului este susţinută și de popularitatea substantivului care denotă rezultatul acțiunii: incendium vs. accendium (termen izolat).

Incendere e curent atît la autorii epocii arhaice: Ennius, Plautus ( 5 oc.), Terentius ( 4 oc.), Cato (3 oc.), cît și la cei din perioada clasică. În Eneida, Vergilius îl folosește cu sens figurat în combinație cu termeni ca: reginam $(1,659)$ „regina”; animum $(4,197$ și 6, 889) „sufletul”; auro squamam $(5,88)$ „cu aur, solzii”; vires $(5,455)$ „puterile”; luctus $(9,500)$,jalea”; celum $(10,895)$ „cerul”; clamoribus urbem $(11,147)$ „cu strigăte, orașul” și doar o dată cu sensul propriu: aras $(3,278)$, ,altarele”. În Bucolice, însă, alături de: laurus $(8,82)$ „dafinul”, și în Georgice, cu: agros $(1,84)$ „cîmpurile”; vepres $(1,268)$ „spinii”; galbaneos odores (4, 264) „mirosurile de rășini”, are doar sens concret. Termenul este folosit și de alți poeți ai perioadei clasice: Propertius, Ovidius (3 oc.), însă mai cu seamă de istorici: Titus Livius (20 oc.), Sallustius (10 oc.), Cæsar (24 oc.), nu lipsește la Cicero (peste 60 oc.) nici în discursuri, nici în tratate, apare la Seneca (16 oc.), mai tîrziu, la Tacitus (10 oc.), dar și la Pliniu Maior (6 oc.), Suetonius (3 oc.) etc.

Mai mult de 40 de ocurențe ale verbului se găsesc în Vulgata $^{37}$, cu sens concret sau figurat fiind folosit de cei mai cunoscuți reprezentanți ai literaturii creștine latine: Tertullianus (4 oc.), Cyprianus (2 oc.), Ambrosius (23 oc.), Augustinus (peste 100 oc.), Hieronymus (17 oc.) etc.. Valorile termenului se diversifică la autorii creștini cu sensuri specifice: „a arde (un martir), a arde (ca jertfă), a aprinde (lumînările) sau a lumina (o traducere)" (Blaise, 1993, s.v. incendo).

Comun în toate perioadele latinității și la toate nivelurile de limbă, incendere nu poate fi considerat caracteristic numai pentru aspectul vorbit al limbii.

\subsection{DRACO}

Cu sensul de 'diavol', cuvîntul s-a păstrat într-un număr restrîns de limbi romanice ${ }^{38}$, însă, în limba latină, sensul de 'diable' al lui draco este atestat atît în Vulgata, cît și la autorii creștini cei mai importanți, începînd chiar cu Tertullian (sec. II-III) (Blaise, 1993, s.v. draco, -onis, 2. 'le dragon, le diable'), care e considerat primul autor creștin de limbă latină și, grație acestui fapt, i se recunoaște meritul de a fi pus bazele lexicului latin creștin, cel puțin în scris. În $A d$ uxorem, cînd autorul vorbește de ipso dracone $(1,6,12)$, el face trimitere la draco ille magnus din Apocalipsa, 12, 9 și 20, 2, tradus în română prin „balaur”, însă identificat în textul biblic cu „diavolul” și cu „satana” 39 .

Augustinus explica pasajul din Psalmi 90, 14 ca fiind o referință la însuşi diavolul: de diabolo dictum est: et conculcabis leonem et draconem (Adnotationes in Iob 38, 615, 2) „despre diavol s-a spus: «și vei călca peste leu și peste balaur»”. Hieronymus este și mai explicit atunci cînd arată că draco este tradus diferit de

\footnotetext{
35 „La lune embrasée par les rayons du soleil” (Gaffiot, 2000, s.v. incendo).

${ }^{36}$ „La lune qu'allument les rayons du soleil” (Gaffiot, 2000, s.v. accendo).

${ }^{37}$ Vezi și incendit ignem ,încinge focul” (Ecclesiasticus, 28, 13; 23, 23).

38 „Cuvântul draco-onis, care desemna „dragonul” (un șarpe mitic), a căpătat numai pe teritoriul de limbă latină din care se va dezvolta româna, albaneza și provențala sensul 'drac”” (Ivănescu, 2000, p. 173-174).

${ }^{39} \mathrm{Apoc}, 12$, 9: „S, Si aruncat a fost Balaurul cel mare, șarpele cel de demult, care se cheamă diavol și Satana [...]” (Anania, 2001, p. 1763); Apoc, 20, 2: „Și l-a prins pe Balaur, pe șarpele cel vechi, care este diavolul și Satana [...]”' (Anania, 2001, p. 1770).
} 
evrei și de greci, stabilind echivalența termenului cu satan și cu diabolus: In die illa inducet deus gladium sanctum [...] et occidet draconem qui est in mari. Tradunt hebrei diabolum, id est criminatorem, quod grecum nomen est, hebraice appellari satan, hoc est aduersarium. (Commentarii in Isaiam 8, 27, 1, 4) „In ziua aceea Dumnezeu va duce sabia sfîntă [...] și va ucide balaurul care e în mare. Evreii traduc: diavolul, adică învinuitorul, care este un cuvînt grecesc. În limba ebraică, e numit satan, adică potrivnicul”.

Din astfel de exemple reiese că sensul de 'diavol' al cuvîntului draco, -onis nu trebuie pus în relație cu latina populară, ci cu latina creștină tîrzie. Faptul că apare în textul biblic și este folosit cu sensul de 'diavol' la cei mai culți autori creștini, dovedește că întrebuințarea sa nu este o particularitate a limbii vorbite de oamenii simpli, ci trebuie pusă în relație cu neologismele semantice din perioada creștină, adică cu sensurile noi, date de creștini unor termeni care existau deja în limbă.

\section{Concluzii}

Examinarea atestărilor de dată latină ale fiecărui termen despre care știm că și-a continuat existența în limbile romanice relevă dinamica acestuia în variantele limbii latine și în diferitele ei epoci. Desigur, evoluția acestor termeni a determinat schimbarea semnificantului, lucru stabilit pe baza legilor fonetice. Demersul nostru nu și-a propus identificarea diferitelor forme ale acestor cuvinte, ci atestarea lor în literatura scrisă (arhaică, clasică și creștină) pentru a stabili în ce măsură un termen care se presupune că aparține latinei vorbite este curent și în limba literară a perioadei respective.

Pe baza exemplelor analizate, am ajuns la concluzia că, dacă un termen aparține atît latinei vorbite, cît și variantei scrise a limbii latine (pentru că numai scrisul poate constitui o variantă a limbii vorbite, uzuale), înseamnă că acel cuvînt aparține de fapt unui fond comun de termeni care nu pot fi considerați caracteristici pentru niciunul din cele două niveluri de limbă. Acești termeni aparțin atît latinei familiare vorbite, cît și latinei clasice scrise, atît latinei din perioada arhaică și clasică, cît și latinei din perioada tîrzie, sînt cunoscuți și întrebuințați atît de oamenii culți (școliți), cît și de cei simpli, chiar analfabeți. Existența în paralel, în latina vorbită și în cea scrisă, în toate epocile, a sinonimelor (parţiale): casa vs. domus, formosus vs. bellus, uetulus vs. senex, auricula vs. auris, gula vs. os, manducare vs. edere, incendere vs. accendere este un argument în favoarea apartenenței etimoanelor unei mari părți a termenilor păstrați în limbile romanice la un fond comun al limbii latine.

Acest fond comun se subsumează în mod natural ideii de limbă comună, o 'latină comună, așa cum o numește Maria Iliescu: „Pour chaque moment de l'histoire du latin on a la possibilité de concevoir un latin commun qui inclut le latin littéraire (écrit et parlé), le latin des couches moyennes, le latin parlé dans les milieux rustiques, le latin parlé par les locuteurs des régions italiques" (Iliescu, 2013, p. 141) ${ }^{40}$. Sintagma este folosită deja de Coșeriu (1954), pentru care 'latina vulgară’ se poate identifica cu 'limba comună a Imperiului Roman.

\section{Bibliografie}

\section{A. Lucrări de referință}

Coșeriu, E. (1954). El llamado "latín vulgar" y lasprimeras differenciaciones romances, Universidad de la Republica, Montevideo. Coșeriu, E. (1997). Sincronie, diacronie și istorie. Problema schimbării lingvistice, versiune în limba română de N. Saramandu, Editura Enciclopedică, București.

Coșeriu, E. (2005). Le latin vulgaire des romanistes, texte rédigé par Benjamín García-Hernández, în La variabilité en langue. Les quatre variations, „Studies in Language”, 6, p. 17-25.

Flobert, P. (2014). Le mythe du latin dit «vulgaire », în Grammaire comparée et variétés du latin. Articles revus et mis à jour (1964-2012), Librairie DROZ, Genève (articol publicat în prima variantă în 1998).

Grandgent, C.H. (1907). An Introduction to Vulgar Latin, D. C. Heath \& Co., Boston.

Haadsma, R. A. \& Nuchelmans, J. (1963). Précis de latin vulgaire, J. B. Wolters, Gröningen.

Herman, J. (1967). Le latin vulgaire, Presses Universitaires de France, Paris.

\footnotetext{
${ }^{40}$ „Pentru fiecare moment al istoriei latinei avem posibilitatea de a concepe o latină comună care cuprinde latina literară (scrisă și vorbită), latina păturilor de mijloc, latina vorbită în mediile rustice, latina vorbită de locutorii regiunilor italice”.
} 
Iliescu, M. (2013). Le soi-disant 'latin vulgaire' et les premières différentiations dans la Romania (Coseriu 1954) et l'état actuel de la question, în Bojoga, E., Boc, O. \& Vîlcu, D.C. (eds), Coseriu: Perspectives contemporaines, Actes du deuxième Colloque International d'études cosériennes CoseCluj 2009, 23-25 septembre, Cluj-Napoca, Roumanie, Tome 1, Presa Universitară Clujeană, p. 137-145.

Ivănescu, G. (2000). Istoria limbii române, ediția a II-a, îngrijirea ediției, indice de autori și indice de cuvinte: Mihaela Paraschiv, Editura Junimea, Iași.

Väänänen, V. (1981). Introduction au latin vulgaire, $3^{\text {ème }}$ édition revue et augmentée, Klincksieck, Paris.

\section{B. Surse}

Anania (2001). Biblia sau Sfinta Scriptură, București, [versiune diortosită după Septuaginta, redactată și adnotată de Bartolomeu Valeriu Anania Arhiepiscopul Clujului], Editura Institutului Biblic și de Misiune al Bisericii Ortodoxe Române.

Blaise, A. (1993). Dictionnaire latin-français des auteurs chrétiens, revu spécialement pour le vocabulaire théologique par Henri Chirat, Brepols (édition originale 1954).

Bloch, R. (1981). Pline l'Ancien, Histoire naturelle, XXXVI, texte établi par J. André, trad. par R. Bloch, commenté par A. Rouveret, Belles Lettres, Paris.

CLTCLT-5 = CETEDOC Library of Christian Latin Texts, Universitas Catholica Lovaniensis Lovanii Novi, Brepols, 2002.

Ernout, A. (1992). Plaute, Comédies, tome IV, Menaechmi, Mercator, Miles gloriosus, texte établi et traduit par Alfred Ernout, Belles Lettres, Paris.

Gaffiot, F. (2000). Le Grand Gaffiot. Dictionnaire latin-français, nouvelle édition revue et augmentée sous la direction de Pierre Flobert, Hachette, Paris.

Marouzeau, J. (1990). Térence, Comédies, tome II : Heautontimorumenos, Phormion, texte établi et traduit par J. Marouzeau, Belles Lettres, Paris.

Septuaginta I = Septuaginta. Geneza, Exodul, Leviticul, Numerii, Deuteronomul, volum coordonat de Cristian Bădiliță, Francisca Băltăceanu, Monica Broșteanu, Dan Slușanschi în colaborare cu pr. Ioan-Florin Florescu, Polirom, s.l., 2004.

Septuaginta [IV] = Septuaginta. Psalmii, Odele, Proverbele, Ecleziastul, Cîntarea Cântărilor, volum coordonat de Cristian Bădiliță, Francisca Băltăceanu, Monica Broșteanu în colaborare cu pr. Ioan-Florin Florescu, traduceri de Cristian Bădiliță, Francisca Băltăceanu, Florica Bechet ș.a., Polirom, s.l., 2006.

Septuaginta IV/2 = Septuaginta. Iov, Ințelepciunea lui Solomon, Ințelepciunea lui Iisus Sirah, Psalmii lui Solomon, volum coordonat de Cristian Bădiliță, Francisca Băltăceanu, Monica Broșteanu în colaborare cu pr. Ioan-Florin Florescu, traduceri de Smaranda Bădiliță, Francisca Băltăceanu, Monica Broșteanu ș.a., Polirom, s.l., 2007.

тов $=$ Ancien Testament, traduction œcuménique de la Bible, édition intégrale, 99e mille, Cerf/Les Bergers et les Mages, Paris, 1979.

Viarre, S. (2005). Properce, Elegies, texte établi, trad. et commenté par Simonne Viarre, Belles Lettres, Paris. 